\title{
Effect of Tailor Made Physiotherapy Protocol with Dry Needling And Kinesio Tapping on Chronic Tennis Elbow With Calcified Common Extensor Origin: A Single Case Study
}

\author{
Paras Joshi Mpt Neuro Md Acu, \\ Senior Physiotherapist, PDU Government Hospital Rajkot.
}

\begin{abstract}
:
Case details: 56 year old lady came to physiotherapy department with outer elbow pain complaint. She was suffering from this condition since last 2 years. After detailed examination we found her elbow extensors were tight, scapular and shoulder muscles were weak and pain sensitivity was increased. She was treated with a tailor made physiotherapy protocols with dry needling, kinesio taping and physiotherapy techniques.

Aim: Aim was to reduce the pain, to gain the normal length and strength of the affected muscles, to strengthen the proximal muscles of shoulder and to improve her daily activities.

Result: Pain came down to 0.5 from 9 on NPRS. Full ROM achieved at elbow. There was absolutely no complaint in performing daily activities.

Conclusion : Chronic tennis elbow can be treated with tailor made physiotherapy treatment.
\end{abstract}

History

\section{Introduction}

A 56 year old lady came to our clinic with pain over outer aspect of left elbow. Pain was local and over musculo-tendinious junction of Extensor Carpi Radialis Longus and Extensor Carpi Radialis Brevis.

Pain started gradually in March 2015. In april 2015 she consulted an Orthopedic surgeon. She had been advised Physiotherapy and NSAIDs. She was on medication till September 2015. Pain intensity fluctuated during these 7 months and eventually there was no pain relief. In October 2015 she consulted an Orthopedic surgeon and was treated by corticosteroid injection with pain killers. After that she got pain relief for 1 month and again pain started. She was advised for one more injection but patient refused. Till November 2016 she was on NSAIDS and other supplementary drugs. She was advised for MRI in Nov 2016 by an Orthopedic Surgeon. MRI showed calcification in Common Extensor Origin. Detail drug history is listed below.

Table 1. Drug history with other treatment

\begin{tabular}{|l|l|l|}
\hline Month and Year & Medicines & Physiotherapy \\
\hline April 2015 (early) & $\begin{array}{l}\text { Diclofinac sodium (50mg)+ PCM (500mgs) } \\
\text { for 10 days }\end{array}$ & $\begin{array}{l}10 \text { sessions of Ultrasound with } \\
\text { unkown doses }\end{array}$ \\
\hline April 2015 (late) & $\begin{array}{l}\text { Domperidone (10mg) + Rabeprazol (20mg) } \\
+ \text { methyl salicylate, etodolac, menthol gel+ } \\
\text { Etodolac }(500 \mathrm{mg}) \text { for } 10 \text { days }\end{array}$ & No \\
\hline May 2015 & $\begin{array}{l}\text { Domperidone (30 mg)+ rabeprazol (40mg)+ } \\
\text { Etodolac }(600 \mathrm{mg}) \text { for 10 days }\end{array}$ & No \\
\hline July 2015 & $\begin{array}{l}\text { Diclofinac, menthol, methyl salicylate spray } \\
\text { for 10 days + Vit B12 tablets }\end{array}$ & No \\
\hline October 2015 & $\begin{array}{l}\text { Calcium carbonate, calcium citrate + methyl } \\
\text { prednisolone acetate (2ml)+ diclofinac gel }\end{array}$ & No \\
\hline November 2015 & $\begin{array}{l}\text { Etoricoxib collagen } \\
\text { peptide,mucopolysaccharide polysulphate } \\
\text { and vit C combinations+ Diclofinac gel }\end{array}$ & Parital immobilization advised \\
January to October 2016 & $\begin{array}{l}\text { Various NSAIDS drugs list by self, no } \\
\text { details available. }\end{array}$ & On and off tennis elbow belt \\
\hline
\end{tabular}

\section{Past History}

Patient had an Road Traffic Accident in December 2014. She was suffering from hairline crack over proximal humerus. She was treated conservatively by immobilization for about 1 month. In December 2016 patient came to our Physiotherapy Department for treatment. Her chief complaint was pain and tenderness over outer aspect of elbow. She complained that she was not able to do few of her daily activities because of pain. (i.e combing hairs, cutting vegetables, making dough etc). She was not able to sleep because of pain. On observation she used to keep her left elbow slightly bent all the time. Her left shoulder was protracted. 
Effect Of Tailor Made Physiotherapy Protocol With Dry Needling And Kinesio....

Table 2. Pain examination.

\begin{tabular}{|l|l|}
\hline Pain Intensity (NPRS) & $9 / 10$ \\
\hline Type of pain & Dull aching sometime throbbing \\
\hline Aggravating Factors & Gripping, Elbow Extension, Elbow Flexion \\
\hline Reliving Factors & Rest \\
\hline Time variation & No significant time variation on pain (night/ day) \\
\hline Tenderness & Grade 3 over lateral epicondyle \\
\hline
\end{tabular}

Table 3. Motor Examination (affected muscles/ joints mentioned)

\begin{tabular}{|l|l||l|l|l|l|}
\hline Group of Muscles (left side) & $\begin{array}{l}\text { MMT } \\
\text { Grade }\end{array}$ & Joint- movement & $\begin{array}{l}\text { ROM } \\
\text { (active) }\end{array}$ & $\begin{array}{l}\text { ROM } \\
\text { (passive) }\end{array}$ & $\begin{array}{l}\text { End } \\
\text { Feel }\end{array}$ \\
\hline Scapular muscles (retractors) & $3+$ & Elbow flexion & $\begin{array}{l}20-110 \\
(90)\end{array}$ & $\begin{array}{l}20-120 \\
(100)\end{array}$ & empty \\
\hline Shoulder flexors & 4 & & $120-30$ & $120-20$ & empty \\
\hline Shoulder abductors & 4 & Elbow extension & & \\
\hline Shoulder extensors & 4 \\
\hline Shoulders external rotators & 4 \\
\hline Elbow flexors (limited ROM) & $3+$ \\
\hline Elbow Extenors (Limited ROM) & $3+$ \\
\hline Forearmsupinators & 4 \\
\hline Forearmpronators & 4 & & \\
\hline Wrist Extensors & $3+$ \\
\hline Wrist flexors & 4 & & \\
\hline Grip & weak \\
\hline
\end{tabular}

Note: Passive ROM were taken from end feel for both flexion and extension

Case description and treatment plan:

Patient came in our department on December 2016 with complaint of local pain on left outer elbow and limited daily activities. After getting detailed subjective history of the patient, posture was evaluated in detail.

\section{Posture:}

Her left side scapula was protracted and left shoulder was drawn anteriorly. Her elbow was bent slightly.It has been examined that her scapular and shoulder girdle muscles were weak along with elbow group of muscles. Details are listed in table 3. Her elbow bending beyond $90^{\circ}$ and extension beyond $90^{\circ}$ was painful. (Difference of active available ROM at both extreme was counted) Passive ROMs were painful after $100^{\circ}$ and $100^{\circ}$ were painful for flexion and extension respectively. (Difference of passive available ROM at both extreme was counted).

We found that there was a significant shortening of elbow extensor group of muscle. MRI suggested calcification at common extensor origin. Patient was explained about the condition she is suffering from. She has been explained that her proximal groups of muscles were weak and need a separate treatment. She was explained that whole physiotherapy protocol may take 3-4 months.

\section{Treatment protocol}

After consultation with chief physician her all medications has been stopped to avoid side effects on her body and organs.

Table 4. Treatment protocol for week 1

\begin{tabular}{|c|c|c|c|}
\hline & Treatment with dose & Days & Reason \\
\hline 1 & Ultrasound $1 \mathrm{MHz} 0.8 \mathrm{w} / \mathrm{cm}^{2}$ & 6 & $\begin{array}{l}\text { To reduce inflammation, } \\
\text { relax tight muscles }\end{array}$ \\
\hline 2 & TENS (90hz) conventional & 3 (alternate) & To relive pain \\
\hline 3 & Dry Needling $^{2}$ & 5 & $\begin{array}{l}\text { To relax muscular bands, } \\
\text { to promote pain relief }\end{array}$ \\
\hline 4 & $\begin{array}{l}\text { Scapular stabilization exercises (with } \\
\text { Kinesio tape on) }\end{array}$ & Daily & $\begin{array}{l}\text { To strengthen fixators } \\
\text { and to reduce load on } \\
\text { elbow extensors }\end{array}$ \\
\hline 5 & Kinesio taping & $\begin{array}{l}\begin{array}{l}\text { Change every } 48 \\
\text { hours }\end{array} \\
\end{array}$ & $\begin{array}{l}\text { To give controlled } \\
\text { mobility }\end{array}$ \\
\hline 6 & Ice application (Home) & Twice a day & $\begin{array}{l}\text { To reduce soreness and } \\
\text { inflammation }\end{array}$ \\
\hline
\end{tabular}

It has been noted that there was $30 \%$ pain relief and $20 \%$ of ease of movements after $1^{\text {st }}$ week treatment.

Table 5. Treatment protocol for week 2 and 3

\begin{tabular}{|l|l|l|l|}
\hline & Treatment with dose & Days & Reason \\
\hline 1 & Ultrasound $1 \mathrm{MHz} 0.8 \mathrm{w} / \mathrm{cm}^{2}$ & $6\left(2^{\text {nd }}\right.$ week $)$ & $\begin{array}{l}\text { To reduce inflammation, relax } \\
\text { ERCL and ERCB, pain relief }\end{array}$ \\
\hline
\end{tabular}


Effect Of Tailor Made Physiotherapy Protocol With Dry Needling And Kinesio....

\begin{tabular}{|l|l|l|l|}
\hline 2 & TENS (90hz) conventional & $\begin{array}{l}3 \quad(\text { alternate }) \quad\left(2^{\text {nd }}\right. \\
\text { week) }\end{array}$ & To relive pain \\
\hline 3 & $\begin{array}{l}\text { Scapular stabilization } \\
\text { exercises + scapular retractor } \\
\text { dynamic exercises in prone+ } \\
\text { shoulder girdle muscle free } \\
\text { exercises (grade 3) }\end{array}$ & Daily & $\begin{array}{l}\text { To gradually strengthen the } \\
\text { proximal muscles }\end{array}$ \\
\hline 4 & Kinesio taping & $\begin{array}{l}\text { Change every 48 } \\
\text { hours }\end{array}$ & To give controlled mobility \\
\hline 5 & $\begin{array}{l}\text { Elbow extensors stretching } \\
\text { passive and active assisted }\end{array}$ & Daily & $\begin{array}{l}\text { To gain natural length of elbow } \\
\text { extensors }\end{array}$ \\
\hline 6 & $\begin{array}{l}\text { Elbow passive ROM } \\
\text { exercises gradually }\end{array}$ & Daily & $\begin{array}{l}\text { To prevent and break adhesions } \\
\text { in joints }\end{array}$ \\
\hline
\end{tabular}

Table 6. Treatment protocol for week 3 to 5

\begin{tabular}{|l|l|l|}
\hline Treatment with dose & Days & Reason \\
\hline $\begin{array}{l}\text { Scapular stabilization exercises + scapular } \\
\text { retractor dynamic exercises in prone+ } \\
\text { shoulder girdle muscle resisted exercises with } \\
500 \text { gms weight. }\end{array}$ & Daily & $\begin{array}{l}\text { To gradually strengthen the } \\
\text { proximal muscles }\end{array}$ \\
$\begin{array}{l}\text { Weight was decided based on pain free elbow } \\
\text { while performing exercise at shoulder with } \\
\text { kinesio tape on }\end{array}$ & & \begin{tabular}{l} 
To give controlled mobility \\
\hline Kinesio taping
\end{tabular} \\
\hline $\begin{array}{l}\text { Elbow extensors stretching passive and active } \\
\text { assisted }\end{array}$ & Daily & $\begin{array}{l}\text { To gain natural length of } \\
\text { elbow extensors }\end{array}$ \\
\hline Elbow passive ROM exercises gradually & Daily & $\begin{array}{l}\text { To prevent and break } \\
\text { adhesions in joints }\end{array}$ \\
\hline
\end{tabular}

\section{Week 5 to 8}

Patient was treated with progressive Resisted Exercises for Shoulder group of muscles. Therabands were used for strengthening exercises. All shoulder ROMs were included in strengthening exercises protocols including rotation. Initially we put less resistance for elbow abductors group as it may give extra load to common extensor origin by giving valgus force at elbow.

Kinesio taping and stretching of elbow extensors were continued and by the end of $6^{\text {th }}$ week we got full passive and active ROM at Elbow.

Free active exercises of elbow extensors and flexors were stared with tapping on at the beginning of $7^{\text {th }}$ week.

Pain intensity was reduced from 9 to 3 on NPRS.

\section{Week 8 to 12}

All progressive resisted exercises were continued with tape on. Resisted exercises for elbow group of muscles were added at $8^{\text {th }}$ week

5 days of Dry needling were added for pain relief along with Ice Application.

Pain intensity was reduced from 3 to 1.5 on NPRS, patient was advised to visit clinic once a week after the $12^{\text {th }}$ week

\section{Week12 to 16}

All exercises have been reduced to 3 days a week from $12^{\text {th }}$ week.

Pain intensity was reduced to 0.5 with all daily activities possible.

\section{Result}

\begin{tabular}{|l|l|l|}
\hline & Before treatment & After treatment \\
\hline Pain NPRS & 9 & 0.5 \\
\hline Elbow flexion active & $20-110(90)$ & $0-140(140)$ \\
\hline Elbow Extension & $\begin{array}{l}120-30 \\
(90)\end{array}$ & $140-0(140)$ \\
\hline Activity limitation & $\begin{array}{l}\text { House hold activities cutting, kneading, } \\
\text { lifting objects, driving two wheelers, } \\
\text { combing hairs }\end{array}$ & \\
\hline
\end{tabular}




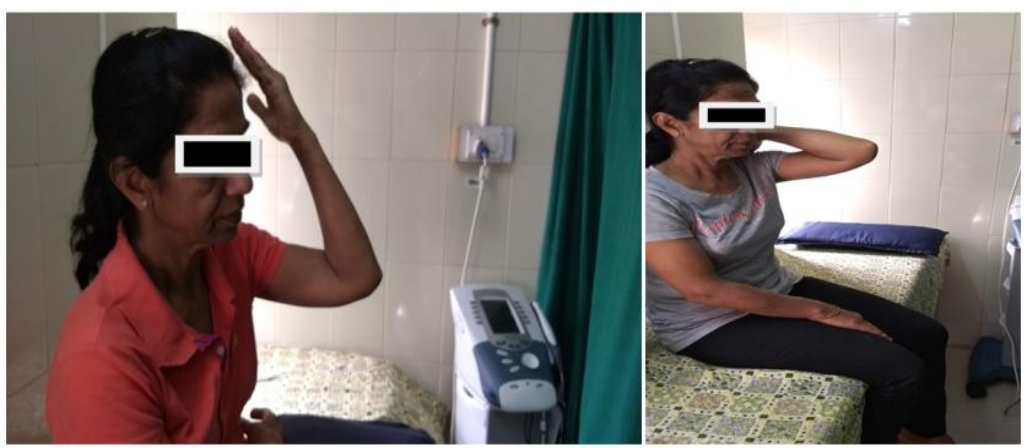

Image 1. Difference between before and after treatment active elbow flexion

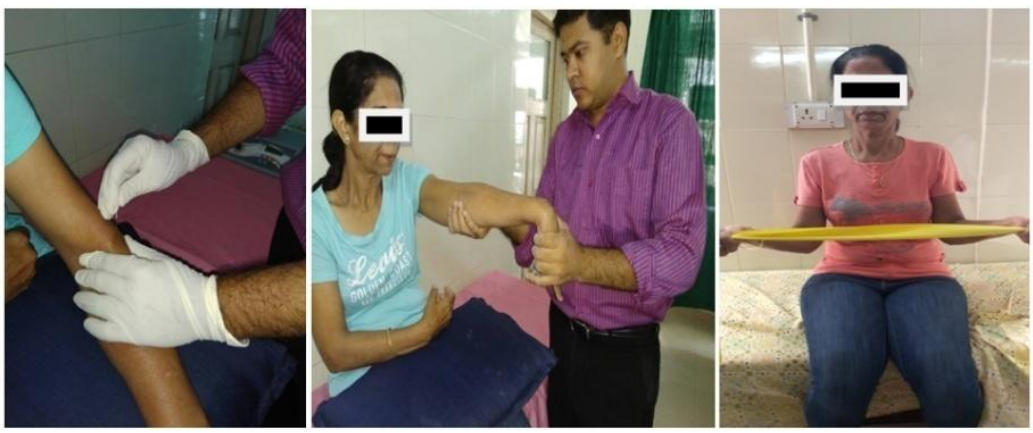

Image 2. Various treatment sessions

\section{Discussion}

Patient came to our physiotherapy department with severe pain and limited ROM. After detailed history evaluation and examination it has been confirmed that patient may have witnessed following sequences.

1. Patient had a history of shoulder trauma. Because of the negligence, immobilization and improper rehabilitation, she might have got the weak stabilizers and shoulder group of muscles .

2. Week fixators and proximal group of muscles might have lead to poor posture and increased load on common extensors group of muscles in elbow. Repetitive daily activities might have caused the condition worsen.

3. Repetitive stress and protective spasm over extensor group of muscles eventually made the muscles tight and limited the activities. Patient took almost only medicines for about 10 months. She also took one dose of methyl prednisolone acetate. Taking pain reliving drugs and methyl prednisolone can give immediate symptomatic pain relief. Because of this pseudo pain relief patient started working with inflamed /injured tendons made the condition worst.

Treatment aim was to reduce the existing initial pain. Therefore she was given dry needling ${ }^{1}$ along with TENS and Ultrasound. At the same time we don't want to put more stress on common extensor origin. She was given advised about rest at home initially and not to work with that hand. To reduce the load on elbow we started working on scapular muscles ${ }^{3}$ first and then on shoulder muscles. We took care that any exercises (i.e shoulder abductors strengthening, External Rotators Strengthening) which put stress on elbow extensors applied carefully and gradually. We gently started moving elbow group of muscles within the pain limit and she was allowed to do all pain free activities after 4 week with kinesio tape on ${ }^{4}$.

We dint do any hurry in strengthening elbow extensor muscles keeping length tension relationship in mind. Shorter muscle cannot be strengthened; strengthening such muscle may increase the pain. We allowed gentle and full lengthening of extensor muscles first with help of Dry Needling, Ultrasound and Manual therapy. Once we achieved full length of elbow extensors muscles, started resisted exercises of elbow group of muscles. Limitation : The study was carried out on single patient as case study which may not be applicable to all patients suffering from tennis elbow.

\section{Conclusion}

Chronic tennis elbow with calcified tendons can be treated conservatively with physiotherapy and dry needling. 


\section{References}

[1]. Physical therapists and performances of Dry needling; an educational resource paper, American PhycialTherapy Association jan 2012.

[2]. Description of dry needling in clinical practice, an educational resource paper, American Physicaltherapy Association feb 2013

[3]. Jiten B Bhatt, Randal G.Middle and lower trapezius strengthening for the management of lateral epicondylgia. A case Report. Jospt. 2013;43, 841-847

[4]. Alireza S, Mohammmad T. Effects of tapping on pain, grip strength and wrist extensor force in patients with tennis elbow. Trauma monthly. Sept 2013, 18(2), 71-74 